\title{
A EFETIVIDADE DA LIBERDADE RELIGIOSA COMO UM DIREITO FUNDAMENTAL
}

\author{
http://dx.doi.org/10.21527/2176-6622.2019.52.51-61 \\ Recebido em: 17/3/2019 \\ Modificações requeridas em: 21/6/2019 \\ Aceito em: 8/7/2019
}

Daniel Barile da Silveira

Pós-doutor em Democracia e Direitos Humanos pela Universidade de Coimbra, Portugal ( Ius Gentium Conimbrigae ). Doutor e mestre em Direito pelo Programa de Pós-Graduação da Faculdade de Direito da Universidade de Brasília (FD-UnB). Professor do Programa de Doutorado e Mestrado em Direito da Unimar (Universidade de Marília). Professor do Programa de Pós-Graduação e do curso de Graduação em Direito do UniToledo (Centro Universitário Toledo, Araçatuba/SP). É advogado e consultor jurídico em Direito Público, sócio do Escritório Barile e Barros Advogados. Tem experiência na área do Direito Público, com ênfase em Direito do Estado, atuando principalmente nos seguintes temas: Direito Constitucional, Supremo Tribunal Federal, Direitos Fundamentais, Poder Judiciário, Formação do Estado Brasileiro, Jurisdição Constitucional, Direito Administrativo do Estado, Direitos Humanos e Sistema Interamericano de Direitos Humanos. http://lattes.cnpq.br/8691251635146768. danielbarile@hotmail.com

Elaine Fachini

Graduada em Direito pela Universidade de Marília/Unimar (2005). Pós-graduada em Docência no Ensino Superior pela Universidade de Marília/Unimar (2017). Mestranda em Direito na Universidade de Marília/ Unimar área de concentração: Empreendimentos Econômicos, Desenvolvimento e Mudança Social. Linha de Pesquisa 1: Relações Empresariais, Desenvolvimento e Demandas Sociais. Bolsista Prosup/Capes da Universidade de Marília/Unimar. http://lattes.cnpq.br/2754195361067583. lainefachini@gmail.com

\section{RESUMO}

Consagrados no artigo 5o da Constituição Federal de 1988, os direitos fundamentais, elencados pelo princípio da dignidade da pessoa humana, atuam como fundamento do Estado Democrático de Direito, porém somente diante de sua efetividade é que se tornam concretos na vida da sociedade. Neste artigo objetiva-se analisar sobre a efetividade dos direitos fundamentais, com especial atenção ao estudo da liberdade religiosa, abordado no contexto das decisões judiciais que buscam dar guarnição ao contexto maior em que ele se insere, qual seja, a laicidade do Estado brasileiro. Entendendo a garantia à liberdade religiosa como um direito fundamental, busca o estudo avaliar, ainda, o recente julgado referente ao ensino religioso nas escolas públicas, abordado na ADI 4.439/2010. Para tanto, utiliza-se a metodologia hipotético-dedutiva, qualitativamente, colhida em bibliografia e jurisprudência pertinentes ao assunto em questão. Conclui-se, por fim, que o direito fundamental à liberdade religiosa e sua efetivação é dever do Estado, pois a ele cabe assegurar um direito igualitário de escolha e que, por ser laico, não deve adotar políticas confessionais, garantindo, assim, o direito fundamental à liberdade religiosa e a dignidade da pessoa, inserta na possibilidade de escolha livre das pessoas em determinar sua religião ou crença.

Palavras-chave: Liberdade religiosa. Direitos fundamentais. Eficácia dos direitos.

\section{THE EFFECTIVENESS OF RELIGIOUS LIBERTY AS THE FUNDAMENTAL LAW}

\section{ABSTRACT}

Established in article 5 of the Federal Constitution of 1988, fundamental rights, listed by the principle of the dignity of the human person, act as the foundation of the Democratic State of Right. But only in view of their effectiveness do they become concrete in the life of society. Through this article, the objective is to analyze the effectiveness of fundamental rights, with special attention to the study of religious freedom, addressed in the context of judicial decisions that seek to fit the larger context in which it is inserted, that is, the laity of the State Brazilian. Understanding the guarantee to religious freedom as a fundamental right, the study seeks to evaluate, also, the recent judgment regarding religious teaching in public schools, addressed in ADI 4439/2010. For that, the hypothetical-deductive methodology is used, qualitatively, collected in bibliography and jurisprudence pertinent to the subject in question. Finally, it is concluded that the fundamental right to religious freedom and its realization is the duty of the State, since it is incumbent upon it to guarantee an equal right of choice and that, because it is a lay person, it should not adopt confessional policies, thus guaranteeing the fundamental right to religious freedom and the dignity of the person, inserted in the possibility of free choice of people in determining their religion or belief.

Keywords: Religious freedom. Fundamental rights. Effectiveness of rights.

\section{SUMÁRIO}

1 Introdução. 2 Direitos Fundamentais e sua Efetividade. 3 A Liberdade Religiosa Como um Direito Fundamental. 4 O Judiciário no Estado Laico e o Direito Fundamental à Liberdade Religiosa. 4.1 O Ensino Religioso no Estado Laico, Como Garantir o Direito à Liberdade Religiosa? 5 Conclusão. 6 Referências. 


\section{INTRODUÇÃO}

A abordagem dos direitos fundamentais, apesar de constantes em anteriores Constituições, somente na Constituição Brasileira de 1988, em seu artigo 5o, tem-se a garantia efetiva desses direitos. O maior avanço, porém, será sua efetividade, como concretização da dignidade da pessoa humana para a formação de uma sociedade civil organizada, na qual o indivíduo tem sua autonomia respeitada em razão da defesa dos direitos fundamentais.

Assim, o escopo do presente artigo é averiguar, entre o rol de garantias dos direitos fundamentais, a efetividade da liberdade religiosa como um direito fundamental específico, assegurado em nossa Constituição Federal de 1988 em seu artigo 50, inciso VI. O escopo final deste estudo é averiguar sua gramática fundamental, constante na abordagem dada pelo poder Judiciário a este direito fundamental, com especial atenção ao julgado na ADI 4.439/2010, que tratou a respeito da possibilidade do ensino religioso nas escolas públicas.

Para análise do abordado adota-se a metodologia hipotético-dedutiva, qualitativamente, colhida em bibliografia e jurisprudência pertinentes à temática. $O$ estudo ora proposto divide-se em três partes. A primeira, de caráter conceitual, estabelecerá a concepção dos direitos fundamentais e como são efetivados no ordenamento pátrio. Para que haja realmente a efetivação os direitos fundamentais devem ser interpretados em sua dimensão hermenêutica mais profunda, ligados ao contexto social e cultural em que se inserem.

$O$ segundo item abrange o direito fundamental à liberdade religiosa, baseado em suas origens e estruturação no ordenamento jurídico brasileiro, com vistas à sua efetividade. Neste sentido, o texto permite uma breve apresentação histórica das origens da liberdade religiosa na Constituição Federal de 1988, identificando o trato constitucional acerca da laicidade do Estado brasileiro, da proteção aos locais de culto e à manifestação da crença.

E, por fim, pretende-se analisar a postura do Judiciário brasileiro diante da ponderação dos princípios da laicidade do Estado laico e a busca da harmonização em razão da garantia ao direito fundamental da liberdade religiosa, verificando julgados pertinentes à temática. Busca-se abordar, mais centradamente, o ensino religioso confessional, cuja temática fora decidida pelo STF em decisão mais recente.

Como avaliação final desse caminho percorrido, perceber-se-á que o direito fundamental à liberdade religiosa deve ser visto como uma efetivação ao direito do indivíduo de escolher livremente sua religião ou crença, ou mesmo de abster-se da escolha, dando sentido ao texto constitucional. O Estado laico, que se revela como um princípio implícito, deve permear sua aplicação em harmonia coma permissividade do exercício da liberdade religiosa, não podendo assumir frontalmente uma política de imposição determinante, ou mesmo de proteção ineficiente deste direito fundamental.

\section{DIREITOS FUNDAMENTAIS E SUA EFETIVIDADE}

Como uma concepção mais geral sobre os direitos fundamentais, podem ser entendidos como aquele conjunto de direitos mais importantes em uma comunidade de pessoas, reconhecidos por uma ordem constitucional. Intimamente relacionados à concretização da dignidade da pessoa humana, tais direitos assumem, na doutrina jurídica, a valoração das prioridades de uma comunidade, na medida em que consolida as reivindicações sociais, visando à evolução do Direito como um todo, bem como forma a base e os elementos de uma sociedade civil organizada (SILVEIRA, 2006).

O estudo dos direitos fundamentais está intimamente ligado à história e ao desenvolvimento do homem em perspectiva e extensão com o tempo. Como explica Hesse, "[...] o conteúdo concreto e a significação dos direitos fundamentais para um Estado dependem de numerosos fatores extrajurídicos, especialmente da idiossincrasia, da cultura e da história dos povos" (2009, p. 26). Em sentido similar, Alexy assim esclarece:

Os direitos do homem têm, porém, independentemente de sua positivação, validez universal. Eles põem, por conseguinte, exigências a cada ordem jurídica. Os direitos do homem tornaram-se vinculativos jurídico-positivamente no plano internacional pelo Pacto Internacional sobre Direitos Civis e Políticos, de 19 de dezembro de 1966 (2008, p. 38). 
De início, questão primordial que se apresenta é se normas de direitos e garantias fundamentais, conforme o artigo 5오 $\$ 1$ 임 da Constituição, têm aplicação imediata. Essas normas são aplicáveis a todos os direitos fundamentais ou estão restritas aos direitos individuais e coletivos previstos apenas no artigo 5?

Como fim imediato do Direito busca-se, portanto, fazer com que os direitos fundamentais sejam efetivamente aplicados. Desta forma, figura injustificável a existência de normas de eficácia limitada que precisam de posterior regulamentação quanto a esse dispositivo, afinal, elas já se materializam como efetivas desde a sua promulgação. Em outros termos, "a questão não está mais em discutir se há ou não aplicação imediata dos direitos fundamentais, que é pressuposto, mas sim, em como realizar e tornar efetiva essa aplicação imediata" (CUNHA JR., 2008, p. 283). Assim sendo, conforme a premissa que aqui se adota, a questão da eficácia dos direitos fundamentais não está no plano da sua validade, mas depende de sua interpretação, com vista a seu problema maior, que é a sua efetividade.

Com a promulgação da Constituição Federal de 1988, passa-se ao pensamento de que a efetividade das normas de direitos fundamentais tem prescrição normativa concretamente regulamenta na vida social. Os direitos individuais, políticos, sociais, culturais, difusos e homogêneos são, portanto, protegidos e promovidos como realidade na vida de pessoas e de grupos (FERRAZ JR., 2008, p. 168) e devem assim ser considerados.

Nesse contexto, para promoção da efetividade das normas constitucionais e, em especial, de direitos fundamentais, necessita-se de criação de garantias sociais, políticas e jurídicas, possibilitadas quando o Estado e a sociedade concedem condições materiais adequadas para os seus membros, gerando riqueza e sua distribuição. Tratando da questão fática, para que ocorra o pleno gozo e a efetivação dos direitos fundamentais, não se pode afastar dessas condições materiais de aplicabilidade (BARROSO, 2009, p. 120). Como afirma Cunha Júnior,

[...] o grande problema que aflige os direitos fundamentais sociais não está em sua declaração ou no reconhecimento formal de suas garantias, mas sim na sua efetivação, que consiste na realização concreta das prestações que compõem seus respectivos objetos (2008, p. 216).

São as garantias judiciais valorizadas pela teoria da constituição da efetividade brasileira, entretanto, que se encontram mais próximas dos indivíduos, pois existindo violação do direito pode o cidadão requerer a proteção judicial ao seu bem jurídico violado. No contexto da aplicabilidade dos direitos fundamentais, há uma tendência ampliada de se valorizar a promoção dos direitos fundamentais por meio de ações judiciais, mas não se aprofundou, até então, uma reflexão mais consistente sobre as garantias sociais e políticas para sua realização, bem como o impacto da judicialização dos conflitos na efetividade dos direitos fundamentais (BARROSO, 2009, p. 121-122).

Isso posto, as normas constitucionais apontam uma obrigatoriedade de comportamento, pois "todas as normas constitucionais, sem exceção, mesmo as permissivas, são dotadas de imperatividade, por determinarem uma conduta positiva ou uma omissão, de cuja realização são obrigadas todas as pessoas e órgãos às quais elas se dirigem" (CUNHA JR., 2008, p. 52).

Para os direitos fundamentais serem efetivos, entretanto, é necessário que sejam interpretados adequadamente, aprofundando o estudo em relação à estrutura das normas de direitos fundamentais. Na visão de Barroso e Barcellos:

Efetividade significa a realização do direito, a atuação prática da norma, fazendo prevalecer no mundo dos fatos os valores e interesses por ela tutelados. Simboliza a efetividade, portanto, a aproximação, tão íntima quanto possível, entre o dever-se normativo e o ser da realidade social (2007, p. 303).

Assim, os direitos fundamentais fazem parte da vida social, premida pelo seu reconhecimento e aplicação concreta. Inclusive, para aqueles que adotam uma postura fundamentada em uma visão naturalística desses direitos, são direitos inerentes ao homem, imprescritíveis e inalienáveis, pois o que faz parte ontologicamente do ser humano não acaba e não pode ser despido. Em uma visão ou em outra, os direitos fundamentais são a base e a finalidade da própria organização política, de maneira que o reconhecimento desses direitos é a própria base do Estado (FERREIRA FILHO, 2005, p. 245). 
Nesta contextualização e diante destas premissas é que a liberdade religiosa se insere, entendida como um direito fundamental de alta carga valorativa. Assim, precisa ser valorado, inclusive.

\section{A LIBERDADE RELIGIOSA COMO UM DIREITO FUNDAMENTAL}

Quando se discorre sobre a liberdade religiosa, deve-se primeiramente verificar quando ela começa a ser percebida. Tal origem vincula-se à autonomia do indivíduo, mais fortemente instaurado nos usos sociais durante a Reforma Protestante de 1517. Agostinho de Hipona, na Idade Média, porém, já havia discutido sobre a temática, o qual, somado aos reformadores Lutero, Calvino e Knox, entendem que a autonomia do indivíduo toma características de uma verdadeira "defesa da liberdade religiosa" (ADRAGÃO, 2002).

O direito à liberdade religiosa foi reconhecido pela Declaração de Direitos do Homem e do Cidadão, na Revolução Francesa de 1789, quando consignou no artigo 10 que "ninguém pode ser molestado por suas opiniões, incluindo opiniões religiosas, desde que sua manifestação não perturbe a ordem pública estabelecida pela lei".

Na América, o tema resultou na Primeira Emenda à Constituição Norte-Americana de 1791. A progressiva laicização do Estado, contudo, pela difusão da ideologia positivista atrelada aos ideais democráticos e republicanos, que se diziam não confessionais, promoveu a separação do Estado e da Igreja, propiciando o surgimento de espaços de afirmação da identidade das minorias religiosas.

No Brasil, os direitos civis de cidadania sofreram o peso da herança colonial, da escravidão e da grande propriedade privada. Esses fatores produziram um país comprometido com o poder privado e com uma ordem social que negava a condição humana à grande parcela da população, os direitos civis só existiam na lei (CARVALHO, 2002). Nesse sentido, explana Silveira:

Como vivemos em uma sociedade pluralista, formada por diversas crenças, valores e concepções de vida, definir direitos de forma universal com referência a valores que pesam mais que outros, destrói com qualquer possibilidade de afirmação do indivíduo enquanto ser dotado de liberdade de escolha, pois vincula seus direitos com o senso geral da sociedade sobre uma hierarquia de valores pré-fixada (2006, p. 61).

Embora a liberdade religiosa tenha sido protegida constitucionalmente desde o Império, não significa que esse direito foi amparado a contento pelo Estado, como posiciona-se Carvalho ao afirmar que "dos direitos que compõem a cidadania, no Brasil, são ainda os civis que apresentam as maiores deficiências em termos de seu conhecimento, extensão e garantia" (2002, p. 210).

Assim, o reconhecimento da liberdade religiosa como direito fundamental, no Brasil, remonta à Proclamação da República, quando então houve um reposicionamento das relações existentes entre o Estado e a Igreja. Sua manifestação social mais explícita funda-se na evolução do reconhecimento à liberdade de pensamento e manifestação, como que um corolário deste princípio.

Com o advento dos tempos atuais, mesmo a liberdade estando presente em anteriores Constituições, foi na Constituição Federal de 1988 em seu artigo 5으, inciso VI, entre os direitos fundamentais, que consignou inviolável a liberdade de consciência e de crença, sendo assegurado o livre exercício dos cultos religiosos e garantida na forma da lei a proteção aos locais de culto e a suas liturgias. Analisando essa normativa, é possível distinguir três direitos distintos protegidos pela norma constitucional: a liberdade de consciência, a liberdade de crença e a liberdade de culto. Embora distintas as liberdades, todas são correlatas. Não há, portanto, sentido concreto de o legislador constitucional resguardar a liberdade de culto sem fazê-lo com relação à crença e à consciência e vice-versa.

Assim, infere-se na visão de Silva que:

Na liberdade de crença entra a liberdade de escolha da religião, a liberdade de aderir a qualquer seita religiosa, a liberdade (ou o direito) de mudar de religião, mas também compreende a liberdade de não aderir à religião alguma, assim como a liberdade de descrença, a liberdade de ser ateu e de exprimir o agnosticismo (2000, p. 251).

Na mesma perspectiva Bastos e Martins ensinam: 
Liberdade de consciência não se confunde com a de crença. Em primeiro lugar, porque uma consciência livre pode determinar-se no sentido de não ter crença alguma. Deflui, pois, da liberdade de consciência uma proteção jurídica que incluiu os próprios ateus e os agnósticos (1988, p. 127).

Como forma de garantir as liberdades citadas o Estado não pode estar associado institucionalmente a Igreja alguma, o que formalmente ocorre no Brasil, desde o Decreto n. 119, de 17 de janeiro de 1890, quando entrou em vigência o regime de separação entre o Estado e a Igreja instaurando o Estado leigo ou laico. Conforme adverte Miranda: "Laicidade significa não assunção de tarefas religiosas pelo Estado e neutralidade, sem impedir o reconhecimento do papel da religião e dos diversos cultos" (2013, p. 28). É nessa perspectiva que explica Garcia:

A constituição, art. 5o, VI estabelece, como visto, a inviolabilidade de crença e, no inciso VIII, a liberdade de não ser privado de direitos por motivo de crença religiosa - o que denota a afirmação da liberdade de crença, de foro íntimo e infensa a qualquer especulação, até mesmo de órgãos governamentais de pesquisa por não se demonstrar de interesse público num Estado laico (2018, p. 152).

Assim, essa liberdade de crer e manifestar-se sobre uma religião impõe uma conduta obrigacional positiva e negativa tanto ao Estado quanto a terceiros. A obrigação positiva, de acordo com Reimer, consiste no "dever do Estado de proteger esse direito individual em face de eventuais violações por parte de particulares e até por autoridades, servidores, empregados ou agentes públicos" (2013, p. 29). Essa obrigação positiva relaciona-se também com terceiros, determinando que estes respeitem as crenças religiosas, suas manifestações e liberdade das pessoas de não professar uma religião, pois, conforme argumenta Ribeiro, "a liberdade religiosa compreende até mesmo a liberdade de não crer, de não ter uma religião" (2002, p. 13).

Já a obrigação negativa, ao revés, pregoa que o Estado não deve discriminar os que creem dos que não creem, buscando, quando possível, em produção normativa situar-se nas generalidades que permitem abranger e tutelar atividades ou comportamentos religiosos e não religiosos (BASTOS; MARTINS, 1988).

Ademais, importante se faz resguardar o direito de determinar a conduta de acordo com a consciência religiosa, estando no núcleo do direito à liberdade religiosa sua livre expressão. É o que se chama de culto, em seu conceito mais mínimo. Duguit observa que

[...] toda religião contém um segundo elemento: o rito ou culto. Para que a liberdade religiosa exista, é preciso que cada um seja inteiramente livre para praticar qualquer culto religioso, que ninguém possa ser molestado por ele, nem impedido, direta ou indiretamente, de praticar o culto correspondente a suas crenças religiosas, e, o inverso $(2005$, p. 232).

As Constituições republicanas passaram a prever a liberdade de culto e também da liberdade individual de ter uma crença específica que melhor se coadune com seus anseios religiosos. Instituíram, assim, a proteção constitucional aos cultos e às liturgias das mais diversas religiões, como um corolário prático do princípio da dignidade da pessoa humana, eis que a declaração de que as pessoas são livres para crerem no que quiserem (ou de não crerem) deve também desdobrar-se sobre suas práticas e ritos.

Nesse diapasão, tem-se a garantia da inviolabilidade dos templos e celebração de atos religiosos conforme previsto no artigo 5o, inciso VI da Constituição Federal de 1988. Entre a liberdade religiosa, consta também a liberdade de organização religiosa, que pode administrar a liturgia, ensinar a doutrina, procurar novos adeptos, formar seus ministros e adquirir bens por contribuições de particulares ou instituições.

No plano infraconstitucional, para tanto, o Código Civil em seu artigo 44, inciso IV, considera as organizações religiosas como pessoas jurídicas de Direito Privado.

Também é assegurado no Código Penal, no Título V, Capítulo I, que trata dos crimes contra o sentimento religioso e do ultraje ao culto e impedimento ou perturbação de ato a ele relativo. Mais especificadamente $o$ artigo 208 nos traz:

Escarnecer de alguém publicamente, por motivo de crença ou função religiosa; impedir ou perturbar cerimônia ou prática de culto religioso; vilipendiar publicamente ato ou objeto de culto religioso:

Pena - detenção, de 1 (um) mês a 1 (um) ano, ou multa.

Parágrafo único. Se há emprego de violência, a pena é aumentada de um terço, sem prejuízo da correspondente à violência. 


\section{Debate}

Segundo Capez (2004, p. 214-218), a ação nuclear da parte final do artigo 208 consubstancia-se no verbo vilipendiar, isto é, tratar com desprezo, desdém, de modo ultrajante o ato ou objeto de culto religioso por meio escrito, por palavras ou por gestos. Para ser considerado ilícito penal, porém, a ação de vilipendiar deve ser praticada no decorrer do ato religioso, diretamente sobre ou contra objeto de culto religioso e ser realizado publicamente, tendo como elemento subjetivo o dolo, a vontade livre e consciente de vilipendiar o ato ou objeto de culto religioso.

O legislador brasileiro procurou, portanto, garantir nas Constituições, principalmente na de 1988 e em legislações específicas, a liberdade religiosa de crença ou de culto como um direito fundamental, buscando também sua efetividade normativa. Com a separação do Estado e da Igreja promovendo a laicidade, configurou-se um equilíbrio em relação à liberdade religiosa como um direito fundamental do indivíduo em professar sua religião, seja ela qual for.

Assim, partindo dessa visão mais genérica sobre a temática aqui discutida, cabe agora entender mais concretamente sobre a efetividade da liberdade religiosa ante o Estado laico na visão do Judiciário brasileiro, como adiante analisado.

\section{O JUDICIÁRIO NO ESTADO LAICO E O DIREITO FUNDAMENTAL À LIBERDADE RELIGIOSA}

A efetividade dos direitos fundamentais e, por conseguinte, da liberdade religiosa, muitas vezes se dá por intermédio do Judiciário. Sendo o Brasil um Estado laico, cabe ao Judiciário amparar a laicidade do Estado junto a liberdade religiosa expressa na sociedade, sem inferir abusos contra qualquer delas.

A ideia de o Judiciário brasileiro reconhecer os processos de mudanças que ocorrem na sociedade, inclusive a busca pela efetividade de um direito fundamental à liberdade religiosa, faz-se essencial e necessário. Assim se identifica:

A evolução do reconhecimento perpassa pela gradual exteriorização das esferas de relação-conflito-reconhecimento num plano prático-material - e não mais idealista - considerando como padrões de reconhecimento intersubjetivo o amor, o direito e a solidariedade. Desse ponto de vista, o esforço passa a ser demonstrar como na sociedade as lutas sociais prestam-se à materialidade do reconhecimento (BORGES DE OLIVEIRA, 2015, p. 61).

Os casos concretos elucidam, ainda mais, a amplitude do direito estudado. No calendário brasileiro, como é sabido, existe a fixação de feriados nacionais religiosos. Se abordada a liberdade religiosa nesse viés, esbarra-se no relacionamento entre Estado e Igreja, como um conflito explícito de direitos constitucionais. Em 1959 o Supremo Tribunal Federal assentou que somente lei municipal, segundo a tradição local, poderia fixar os feriados religiosos, preponderando que as leis municipais podem expressar o sentimento religioso do município, seguindo o conceito vigente na sociedade da época. Contemplou-se, com essa decisão, o disposto na Lei 605 de 5 de janeiro de 1949 (BRASIL,1959).

Em outro caso julgado tem-se a discussão ocorrida no Tribunal Regional Federal da 1a Região em processo ajuizado contra a União, por força da Lei 6.802 de 1980, a qual oficializou Nossa Senhora Aparecida como padroeira do Brasil e fixou feriado nacional no dia 12 de outubro. Como argumento preponderante, invocou-se a ilegalidade e antijuridicidade da norma, argumentando que a minoria evangélica residente no país teria sua liberdade religiosa afrontada por esse feriado, pois causaria preconceito e discriminação religiosa. Sustentou-se, também, a violação do artigo 19, inciso I da Constituição Federal de 1988. Tal pretensão, contudo, não alcançou êxito, em decorrência de decisão da desembargadora federal Maria Isabel Gallotti Rodrigues, diante de que, ponderando sobre a fixação de um feriado religioso, mesmo por lei, não causaria injúria aos adeptos de outras religiões. Reconheceu-se, assim, a maioria católica e a confirmação de ter um dia especial para veneração da figura religiosa homenageada, consectária de uma manifestação cultural relevante, expressão da maioria da população religiosamente orientada (BRASIL, 2019a).

Nesse diapasão, inclui-se a discussão da utilização dos símbolos religiosos em instituições públicas, gerando inclusive um embate entre o Ministério Público Federal e a Advocacia-Geral da União sobre a exposição de crucifixos em prédios públicos. Em caso julgado no Supremo Tribunal Federal, decidiu-se improcedente o pedido do Ministério Público Federal embasado na compreensão de que a laicidade do Estado não configura 
uma negativa de manifestação de fundo religioso, como a manutenção de crucifixos em prédios de uso público. A decisão baseou-se na possibilidade de convivência entre laicidade e manifestações religiosas presentes na identidade nacional, que também é cultural (BRASIL, 2010).

Infere-se aqui os casos em que a liberdade religiosa consiste apenas na liberdade para professar fé em Deus, não cabendo impedir a demonstração da fé de outrem, Destacando-se que a laicidade do Estado brasileiro não se traduz em oposição ao fenômeno religioso, possibilitando a convivência do Estado laico com símbolos religiosos, entre eles os crucifixos, as imagens, monumentos e nomes de logradouros ou de cidades, pois refletem a história e a identidade nacional ou regional.

Nos casos mencionados, interpretou-se a cultura religiosa prevalecente sobre o direito laico perpetuando as tradições e a cultura. O patrimônio histórico, cultural e os feriados nacionais estão integrados à sociedade de forma inquestionável, entretanto são autodeterminantes quanto aos prédios públicos, não havendo opção garantida pelo princípio da dignidade da pessoa humana, do cidadão que não comunga com aquela fé, escolher estar no local, pois este se submete ao serviço público ali prestado.

Nesse sentido, a arguição por tradições e costumes para sustentação de símbolos religiosos não se configuraria, pois a laicidade do Estado foi alçada à condição de princípio constitucional, na Constituição de 1891 configurada desde a edição do Decreto 119-A de 7 de janeiro de 1890, rompendo com o antigo Estado Confessional no período do Brasil-Colônia (1500 a 1824) e Brasil-Império (1824 a 1891).

Na mesma toada, Sarmento (2007) explana que a laicidade impõe ao Estado uma postura de neutralidade diante das diversas religiões existentes na sociedade, ficando proibido tomar partido em questões de fé, não podendo favorecer ou atrapalhar, pois está vinculado às premissas da liberdade religiosa e da igualdade como valores constitucionais. Em uma sociedade pluralista com variadas crenças e afiliações religiosas a laicidade apresenta-se como um instrumento para o tratamento igualitário de todos. Diante do pluralismo religioso o posicionamento do Estado por uma religião implicaria desigualdade no tratamento em relação àqueles que não abraçam o credo privilegiado.

\subsection{O Ensino Religioso no Estado Laico, Como Garantir o Direito à Liberdade Religiosa?}

Em consonância às discussões antes debatidas, bem como dando densidade ao tema central do artigo, faz-se importante entender como o Supremo Tribunal Federal se posiciona sobre o ensino religioso confessional em escolas públicas e privadas, tema discutido na Ação Direta de Inconstitucionalidade julgada.

Partindo da elucidação constitucional, o parágrafo §1ำ do artigo 210 da Constituição Federal de 1988 traz que o ensino religioso será de matrícula facultativa e constituirá disciplina dos horários normais das escolas públicas de Ensino Fundamental. Observando que o preceito está inserido no Título VII da Constituição, que trata da ordem social, no seu Capítulo III, Seção I, sobre a educação, orientado pelos princípios estabelecidos no artigo 206, especificando o caput do artigo 210, o qual orienta que serão fixados conteúdos mínimos para o Ensino Fundamental de maneira a assegurar formação básica comum e respeito aos valores culturais e artísticos, nacionais e regionais.

A matéria em questão foi regulada pelo legislador infraconstitucional por meio da Lei $n^{\circ} 9.394$, de 20 de dezembro de 1996, a Lei de Diretrizes e Bases da Educação Nacional - LDB - a qual, tratando do Ensino Fundamental, previu no artigo 33 a oferta de ensino religioso em duas modalidades, podendo ser confessional, conforme opção religiosa do aluno ou responsável, a cargo das respectivas igrejas ou confissões; ou interconfessional, mediante acordo entre as diversas entidades religiosas. No ano seguinte, porém, a Lei $n^{\circ} 9.475$, de 23 de julho de 1997, promoveu a primeira alteração na LDB e conferiu nova redação ao artigo 33, assegurando o respeito à diversidade cultural religiosa do Brasil.

Assim, sobre a questão levantada, Moraes menciona que o artigo 210, §1ㅇ da Constituição Federal de 1988, deverá buscar a adequação com as liberdades públicas de culto religioso e a previsão do Estado laico. Esclarece também estar presente no dispositivo dupla garantia constitucional que não se poderá instituir, na escola pública, o ensino de uma única religião ou doutrinação à determinada fé e que a liberdade das pessoas se matricularem ou não na matéria oferecida configuraria a plena liberdade religiosa, inclusive a liberdade ao ateísmo (MORAES , 2005, p. 120) 
No mesmo pensamento, ao comentar o dispositivo, Silva ressalta que "é um direito do aluno religioso ter a possibilidade de matricular-se na disciplina, mas não lhe é dever fazê-lo". E completa: "Nem é disciplina que demande provas ou exame que importem reprovação ou aprovação para fins de promoção escolar". Só estão obrigadas as escolas públicas e de Ensino Fundamental, posto que as privadas "podem adotá-la como melhor lhes parecer, desde que não imponham determinada confissão religiosa a quem não o queira" (MORAES, 2005, p. 252-253).

Para Bastos e Martins, o aluno tem o "direito de obter o ensino religioso e o direito de optar entre o ensino de uma religião ou outra de acordo com suas convicções pessoais". Afirmam que esse direito individual do aluno para requerer acesso ao ensino religioso tem a contrapartida no dever de o Estado propiciar que ocorra nas escolas públicas, pois o "Estado não se encontra obrigado a oferecer ele próprio o ensino religioso", com o oferecimento do ensino religioso ficando a cargo das entidades religiosas. Já as escolas particulares, que podem ser confessionais, segundo o artigo 20, inciso III, da LDB, são livres para oferecer ou não o ensino religioso, cabendo ao educando ou responsável "escolher nesses casos a escola confessional que mais se adapte a suas crenças e conviç̧ões pessoais" (BASTOS; MARTINS, 1988, p. 595-601).

Ferraz Jr. aborda o tema acerca do parágrafo $\$ 1$ ㅇ do artigo 210 da Constituição Federal de 1988, esclarecendo que a "exegese do preceito deve ser feita à luz do direito à educação e da liberdade de religião, considerando o ensino religioso uma projeção da liberdade de religiosa e sua concretização" (FERRAZ JR., 2008, p. 25).

Como argumento comparativo sobre o ensino religioso, tem-se que nos Estados Unidos a religião é enraizada na sociedade, mas a Constituição determina que as escolas públicas sejam neutras em questões religiosas. Os alunos podem manifestar livremente suas crenças, inclusive com uso de símbolos e vestimentas religiosas, mas os professores são proibidos de manifestar qualquer religião. $O$ ensino religioso integra os currículos escolares sob a forma de história da religião, estudo literário da bíblia ou de estudo sociológico da religião como fenômeno cultural, conforme afirmação de Sepúlveda:

Segundo um levantamento com relação ao ensino religioso nas escolas públicas americanas, o ensino confessional não pode ser ministrado. Todavia, a manifestação religiosa dos alunos não sofre qualquer restrição. São permitidos símbolos e vestimentas religiosas, e uma alimentação religiosamente prescrita. Os alunos podem, sem proselitismo, tentar convencer seus colegas. Podem também distribuir literatura religiosa, assim como reunir-se no ambiente da escola com propósitos religiosos (2013, p. 9).

Importante ressaltar que os Estados Unidos, como um Estado laico, defendem a não diferenciação entre seus alunos nas escolas públicas, como dispõe a Suprema Corte Americana, segundo expõe Lupu, no The Pew Forum on Religion:

As decisões da Suprema Corte sobre expressão religiosa, patrocinada oficialmente nas escolas consistentemente, distinguem entre atividades religiosas como adoração ou leitura da Bíblia, que são projetadas para incutir sentimentos e valores religiosos, e "ensinar sobre religião", que é tanto constitucionalmente permissível quanto educacionalmente apropriado. Em várias ocasiões, membros da Corte sugeriram que as escolas públicas ensinassem "a Bíblia como literatura", incluíssem lições sobre o papel da religião e instituições religiosas na história ou oferecessem cursos sobre religião comparada (LUPU, 2007, p. 7, tradução nossa).

Ainda sobre o ensino religioso, a Suprema Corte do Brasil tratou o tema conjugado na Ação Direta de Inconstitucionalidade - ADI - proposta pela Procuradoria Geral da República - ADI 4.439/2010, postulando interpretação do Acordo com a Santa Sé para assentar que o ensino religioso em escolas públicas só pode ser não confessional. Buscou-se, portanto, declarar a proibição da admissão de professores que representem confissões religiosas e, subsidiariamente, pugnou-se pela inconstitucionalidade parcial da norma concordatária para suprimir do texto do artigo 11, parágrafo $§ 1$ 1 a expressão "católico e de outras confissões religiosas".

Com a ADI buscou-se assentar que o ensino religioso em escolas públicas deve ter natureza não confessional, proibindo a admissão de professores na qualidade de representantes das confissões religiosas que, segundo a tese proposta, integraria o ensino religioso com o laicismo do Estado brasileiro. A disciplina traria conteúdo de história e sociologia das religiões e também posições não religiosas sem partidarismo dos educadores. Argumenta-se, na petição da ADI 4.439, que o Estado não pode apoiar a religiosidade em detrimento da não religiosidade por ser um Estado laico. 
Após discussões sobre o tema, em 27 de setembro de 2017 o Supremo Tribunal Federal finalmente concluiu o julgamento sobre ensino religioso nas escolas públicas. Em sessão plenária julgou improcedente a Ação Direta de Inconstitucionalidade - ADI 4.439/2010. Por maioria dos votos, os ministros entenderam que o ensino religioso nas escolas públicas brasileiras pode ter natureza confessional, ou seja, vinculado às diversas religiões.

Decidiu-se que ensino religioso nas escolas públicas será de conteúdo confessional e matrícula facultativa, respeitando o binômio da laicidade do Estado e liberdade religiosa. Possibilitou-se a igualdade de acesso e tratamento a todas as confissões religiosas, em conformidade com artigo $210, \S 1^{\circ}$ da Constituição Federal de 1988 e abarcando a constitucionalidade do artigo 33, caput e $\S \S 10$ e 2 da Lei de Diretrizes e Bases da Educação Nacional e do Estatuto Jurídico da Igreja Católica no Brasil promulgado pelo Decreto 7.107/2010.

Em dezembro do mesmo ano o Conselho Nacional de Educação (CNE) aprovou a Base Nacional Comum Curricular, a qual dita que Estados e municípios tiveram dois anos para instituir a Base em suas grades curriculares, ou seja, a revisão dos currículos aconteceu em 2018, estando atualmente a nova Base já em uso, constando o ensino religioso de maneira confessional na grade da rede pública, conforme orientação do STF.

São modelos de estudo religioso: o não confessional, pelo qual as aulas de ensino religioso consistem na exposição neutra e objetiva, tratando da prática, da história e dimensão social das diferentes religiões, incluindo posições não religiosas; o modelo confessional, em que uma ou mais confissões são objeto de estudo e, por fim, o interconfessional, pelo qual o ensino de valores e práticas religiosas se dá com base em elementos comuns entre credos dominantes na sociedade.

Verifica-se, desse modo, que no texto constitucional o legislador optou por uma educação que vise a formar cidadãos de maneira ampla, não de forma segmentada. Assim, a educação deve pautar-se pelo respeito às diferenças e fomento à reflexão crítica com vistas ao desenvolvimento pleno da pessoa. Logo, o ensino religioso deve atentar para isso, uma vez que se insere como uma das vertentes dessa integralidade (FISCHMANN, 1998, p. 970).

Nesse sentido, deve o Estado direcionar um direito igualitário para as religiões de uma forma geral, por ser um Estado laico. Uma política estatal que favoreça uma ou algumas religiões seria vedada pela Constituição Federal, representando uma coerção indireta sobre os que não professam aquela crença, de que suas crenças são menos dignas de serem favorecidas.

A grande questão está em saber conciliar as diversidades, articulando para não haver comprometimento com uma e nem oprima a outra. $O$ ensino de elementos religiosos fornece ao indivíduo meios de poder escolher uma orientação religiosa, caso deseje. Rechaça-se, destarte, uma opção induzida por influência, provinda de um modelo de ensino religioso confessional.

\section{CONCLUSÃO}

Para serem efetivos, os direitos fundamentais devem ser interpretados adequadamente, em razão de sua complexidade e da dimensão organizativa de nossa sociedade plural hodierna. Considerando serem a base e a finalidade de uma organização política, o reconhecimento desses direitos faz erigir a própria essência do Estado, legitimando a sua existência e o seu papel social.

No plano da liberdade religiosa, garantido explicitamente na Constituição Federal de 1988, em seu artigo 50, inciso VI, consignou-se ser inviolável a liberdade de consciência e de crença, sendo assegurado o livre exercício dos cultos religiosos e garantida na forma da lei a proteção aos locais de culto e suas liturgias, visando também à laicidade do Estado brasileiro. Tal concepção não foge à historicidade das Constituições republicanas brasileiras, as quais passaram a prever a liberdade de culto como um direito fundamental à liberdade individual de crença e a proteção constitucional aos cultos e às liturgias das mais diversas religiões.

Como antes referido, em diversos casos analisados em relação à concretização da laicidade do Estado brasileiro, em especial sobre a promulgação de feriados religiosos e símbolos de uma determinada religião em espaço público, averiguou-se que a interpretação da cultura religiosa prevalece sobre o direito laico, perpetuando as tradições ao invés da reflexão crítica sobre os fatos, devendo a laicidade ser um instrumento de tratamento igualitário de todos em uma sociedade de múltiplas crenças. 
Em relação ao ensino religioso, o legislador constituinte, no 210, §1ㅇ da Constituição Federal de 1988, tentou buscar a adequação entre liberdades públicas, liberdade religiosa e Estado laico, tendo como garantia constitucional que na rede pública não se configura o ensino de uma única religião, constituindo escolha do indivíduo cursar ou não determinada matéria, assumindo plenamente sua liberdade religiosa, incluindo a liberdade ao ateísmo.

Neste contexto, a Ação Direta de Inconstitucionalidade - ADI 4439/2010 - julgada improcedente em setembro de 2017 pelo Supremo Tribunal Federal, manteve-se posição anterior referente ao Decreto 7.107/2010, ditando que o ensino religioso nas escolas públicas será de conteúdo confessional e matrícula facultativa, respeitando a laicidade do Estado e a liberdade religiosa para dar igualdade de acesso e tratamento a todas as confissões religiosas. Inserido desde este ano de 2019, o ensino religioso confessional, na rede pública de Ensino Fundamental, tornou-se uma possibilidade concreta no regime jurídico brasileiro.

Assim, ao Estado cabe o dever de possibilitar um direito igualitário à liberdade de escolha da religião, por sua laicidade, porém é repelido o comportamento público de favorecer uma ou outra religião, decisão política que agride verticalmente a interpretação mais correta da Constituição Federal, de maneira a desprestigiar o direito fundamental à liberdade religiosa e à dignidade da pessoa em escolher sua religião e crenças.

Conclui-se, por fim, que o Estado brasileiro, ao atribuir o ensino religioso confessional às escolas públicas de Ensino Fundamental, pode ferir o direito fundamental de liberdade de escolha religiosa constante em nossa Carta Magna. Abre-se, destarte, a possibilidade de promoção de uma determinada religião, professada por uma maioria, em detrimento de outras religiões professadas pelas minorias.

Assim sendo, apesar de o STF ter constitucionalizado o ensino religioso confessional, este deveria ser aplicado como área do conhecimento histórico, devido à diversidade de religiões e doutrinas existentes até mesmo dentro do próprio cristianismo. Não pode ser entendido, desta forma, como uma obrigatoriedade vinculativa para as escolas públicas como forma mais concreta de que haja garantia do direito fundamental à liberdade religiosa, vertida pela efetividade dos direitos nesta seara.

\section{REFERÊNCIAS}

ADRAGÃO, Paulo Pulido. A liberdade religiosa e o Estado. Coimbra, PT: Almedina, 2002.

ALEXY, Robert. Teoria dos Direitos Fundamentais. Trad. Virgílio Afonso da Silva. São Paulo, SP: Malheiros, 2008.

BASTOS, Celso Ribeiro, MARTINS, Ives Gandra. Comentários à Constituição do Brasil. São Paulo, SP: Saraiva,1988. V. 2.

BARROSO, Luís Roberto. O Direito Constitucional e a efetividade de suas normas: limites e possibilidades da Constituição brasileira. 9. ed. Rio de Janeiro, RJ: Renovar, 2009.

BARROSO, Luís Roberto; BARCELLOS, Ana Paula de. O começo da história: a nova interpretação constitucional e o papel dos princípios no direito brasileiro. In: SILVA, Virgílio Afonso da (org.). Interpretação Constitucional. São Paulo, SP: Malheiros, 2007. p. 217-316.

BORGES DE OLIVEIRA, Emerson Ademir. A estética da luta por reconhecimento na efetivação dos direitos humanos. Revista Argumentum, Marília, SP, v. 16, p. 55-72, jan./dez. 2015. Disponível em: http://ojs.unimar.br/index.php/revistaargumentum/ article/view/40/25. Acesso em: 5 fev. 2019.

BRASIL. Constituição Federal de 1988. Disponível em: http://www.planalto.gov.br/ccivil_03/consti-tuicao/constituicaocompilado.htm. Acesso em: 3 fev. 2019.

BRASIL. Código Civil - Lei 10.406 de 10 de janeiro de 2002. Disponível em: http://www.planalto.gov.br/ccivil_03/leis/2002/ I10406.htm. Acesso em: 3 fev. 2019.

BRASIL. Código Penal - Decreto Lei 2.848 de 7 de dezembro de 1940. Disponível em: http://www.planalto.gov.br/ccivil_03/ Decreto-Lei/Del2848.htm. Acesso em: 3 fev. 2019.

BRASIL. Lei de Diretrizes e Bases da Educação Nacional - Lei n 9.394, de 20 de dezembro de 1996. Disponível em: http://www. planalto.gov.br/ccivil_03/LEIS/L9394.htm. Acesso em: 3 fev. 2019.

BRASIL. Lei no 6802, de 30 de junho de 1980. Disponível em: http://www.planalto.gov.br/ccivil_03/leis/I6802.htm. Acesso em: 3 fev. 2019.

BRASIL. Supremo Tribunal Federal. Ação Direta de Inconstitucionalidade no 4.439/2010. Disponível em: http://www.stt.jus.br/ portal/geral/verPdfPaginado.asp?id=635016\&tipo=TP\&descricao=ADI\%2F4439. Acesso em: 4 fev. 2019.

BRASIL. Supremo Tribunal Federal. Agravo de Instrumento no 20526/1959. Disponível em: http://redir.stf.jus.br/paginadorpub/ paginador.jsp?docTP=AC\&docID=7409. Acesso em: 4 fev. 2019. 
BRASIL. Tribunal Regional Federal da 1a Região. Apelação Cível no 2000.34.00.027768-5-DF. Disponível em: https://trf-1.jusbrasil.com.br/jurisprudencia/2301461/apelacao-civel-ac-27768-df-20003400027768-5. Acesso em: 4 fev. 2019a.

BRASIL. Ação Civil Pública 0017604-70.4.03.6100. 3a Vara da Justiça Federal em São Paulo. Disponível em: http://www.jfsp.jus. br/foruns-federais. Acesso em: 4 fev. 2019b.

CAPEZ, Fernando. Curso de Direito Penal. 3. ed. São Paulo, SP: Saraiva, 2004. Vol.ume 2.

CARVALHO, José Murilo. Cidadania no Brasil: o longo caminho. Rio de Janeiro/RJ: Civilização Brasileira, 2002.

CUNHA JÚNIOR, Dirley da. Controle Judicial das Omissões do Poder Público. 2. ed. rev. e atual. São Paulo, SP: Saraiva, 2008.

DUGUIT, Leon. Manual de Derecho Constitucional. Granada, ES: Comares, 2005.

FERRAZ JR., Tércio Sampaio. Introdução ao Estudo do Direito: técnica, decisão e dominação. São Paulo, SP: Atlas, 2008.

FERREIRA FILHO, Manoel Gonçalves. Direitos Humanos Fundamentais. 7. ed. São Paulo, SP: Saraiva, 2005.

FISCHMANN. Roseli. Estratégias de superação da discriminação étnica e religiosa no Brasil. In: PINHEIRO. Paulo Sérgio; GUIMARÃES. Samuel Pinheiro (org.). Direitos humanos no século XXI: seminário parte II. São Paulo, SP: Ipri, 1998.

GARCIA, Maria. A Constituição e o ensino religioso nas escolas públicas. In: GRIM, Brian J.; LAZARI, Rafael; SORIANO, Aldir Guedes (org.). Liberdade religiosa e desenvolvimento econômico. Belo Horizonte, MG: Editora D’Plácido, 2018. p. $143-156$.

HESSE, Konrad. Significado dos Direitos Fundamentais. Trad. Carlos dos Santos Almeida. In: KONRAD, Hesse. Temas fundamentais do Direito Constitucional. São Paulo, SP: Saraiva, 2009. p. 23-72.

LUPU, Ira. et al. Religion in the Public Schools. The Pew Forum on Religion \& Public Life. Washington, DC, p. 1-17, May 2007. Available from: https://www.pewresearch.org/wp-content/uploads/sites/7/2007/05/religion-public-schools.pdf. Cited: 3 mar. 2019.

MIRANDA, Jorge. Estado, liberdade religiosa e laicidade. Revista Eletrônica Gaudium Sciendi. Lisboa, PT, n. 4, p. 20-48, jul. 2013. Disponível em: http://www2.ucp.pt/resources/Documentos/SCUCP/GaudiumSciendi/Revista\%20Gaudium\%20Sciendi_ N4/6.\%20jmirandaEstado\%20\%20liberdade\%20religiosa\%20e\%20laicidade.pdf. Acesso em: 3 mar. 2019.

MORAES, Alexandre de. Curso de Direito Constitucional. 13.ed. São Paulo: Atlas, 2005.

REIMER, Haroldo. Liberdade religiosa na história e nas constituições do Brasil. São Leopoldo: Oikos, 2013.

RIBEIRO, Milton. Liberdade Religiosa - uma proposta para debate. São Paulo, SP: Mackenzie, 2002.

SARMENTO, Daniel. O crucifixo nos tribunais e a laicidade do Estado. Revista Eletrônica da Procuradoria da República de Pernambuco, Pernambuco, RE, ano 5, maio 2007. Disponível em: http://www.prpe.mpf.mp.br/internet/index.php/internet/Revista-Eletronica/Revista-Eletronica/2007-ano-5/O-Crucifixo-nos-Tribunais-e-a-Laicidade-do-Estado. Acesso em: 5 fev. 2019.

SEPÚLVEDA, José Antônio. Estados Unidos. Revista Eletrônica Olé - Observatório da Laicidade do Estado. NEPP-DH/UFRJ, Rio de Janeiro, RJ, p. 1-11, 2013. Disponível em: http://www.nepp-dh.ufrj.br/ole/textos/eua.pdf. Acesso em: 3 mar. 2019.

SILVA, José Afonso da. Curso de Direito Constitucional Positivo. 17. ed. São Paulo, SP: Malheiros, 2000.

SILVEIRA, Daniel Barile da. Paradigmas de interpretação constitucional: desafios ao entendimento das sociedades modernas. Revista Eletrônica da Universidade Federal de Santa Maria - UFSM, Santa Maria, RS, v. 1, n. 1, p. 51-63, mar. 2006. Disponível em: https://periodicos.ufsm.br/revistadireito/article/view/6764/pdf. Acesso em: 5 fev. 2019.

SILVEIRA, Daniel Barile da. Os direitos fundamentais, sua efetividade e necessidade de declaração. In: BORGES DE OLIVEIRA, Emerson Ademir et al. Federalismo à brasileira. Disponível em: https://www.migalhas.com.br/FederalismoaBrasileira/124,MI288564,81042-Os+direitos+fundamentais+sua+efetividade+e+necessidade+de+declaracao. Acesso em: 5 fev. 2019. 